\title{
Kecenderungan Kebebasan Berfikir Mahasiswa Melayu Muslim Malaysia Dekad 1970-an
}

\author{
Freedom of Thought among 1970s Malaysian Malay Muslim Students \\ MUHAMAD FAISAL ASHAARI* \& MOHAMMAD HASAN SHARAFI CHE MOHD ADLI ${ }^{1}$
}

\begin{abstract}
Each student era has its own distinctive thinking pattern that stimulate their activism. This can be seen in their activities in 70s. They are vocal and aggressive in mobilizing associations and groups to approach current issues in line with the young souls who have a high and passionate idealism. This is qualitative study using content analysis methodology from various sources in the form of books, journals, articles and electronic materials related to this topic. There are four factors that stimulate students' critical thinking namely socioeconomics, dakwah, politics and the Universities and University Colleges Act (AUKU). Many of their activities are beneficial, but sometimes it is in contrary to the mainstream of society and the government policy. This article analyses the above four factors that related to 1970s Malaysian Malay student activities. Students were heavily influenced by the Nationalist Islamist idealism after the May 13, 1969 incident based on religious and national inspiration. The student movement also changed from the nationalist movement to religious-based movement that called on religion as a way of life. Malay nationalism was still a part of idea in freedom of thinking in their movement spirit following the fate of Malay community who were still retreating after independence in 1957.
\end{abstract}

Keywords: freedom of thought, Malaysia, student activitism, student movement, university

Mahasiswa merupakan sekelompok anak muda yang menuntut ilmu di Institut Pengajian Tinggi pada tahap pengajian sarjana muda, sarjana dan kedoktoran. Mereka merupakan golongan yang bercita-cita tinggi dan bersemangat merealisasikan cita-cita mereka. Mereka menganggap halangan yang ada di sekeliling sebagai halangan yang kecil yang dapat dijatuhkan dengan semangat mereka yang ada. Shamsul Amri Baharuddin (2007) menyatakan bahawa mahasiswa menyimpan 1001 idealisme serta idaman peribadi masing-masing yang dimotivasikan oleh persepsi indah dan sempurna yang mereka rasai dan alami di sekeliling mereka. Mereka juga akan memikir sambil merancang untuk menyusun langkah ke arah merealisasikan cita-cita atau keinginan yang diidamkan itu. Dalam usia yang muda ini, mereka berusaha membina identiti dan jati diri serta mencari pengalaman hidup yang masih panjang.

Dalam pada itu, ada pengkaji seperti Weiss (2016) yang mengaitkan mereka dengan darah muda yang bersifat terburu-buru, sikap melulu, kurang berhikmah dan tidak matang. Menurut Muhammad Abu Bakar (1973) mahasiswa senantiasa muda dan mudah dibakar oleh api idealisme yang membuak-buak.

1 Muhamad Faisal Ashaari*(corresponding author), Ph.D., senior lecturer at Centre of Human Well-Being and Community, Faculty of Islamic Studies, Universiti Kebangsaan Malaysia, 43600 BANGI, Selangor, Malaysia, email: faisal@ukm.edu.my; Mohammad Hasan Sharafi Che Mohd Adli, M.A. candidate at Centre of Human Well-Being and Community, Faculty of Islamic Studies, Universiti Kebangsaan Malaysia, 43600 BANGI, Selangor, Malaysia, email: p93095@siswa.ukm.edu.my.

https://doi.org/10.24035/ijit.15.2019.009 
Pandangan yang sama juga dikongsikan oleh Shamsul Amri Baharuddin (2007) yang menyifatkan sikap kumpulan umur mahasiswa merupakan kumpulan umur yang mempunyai ciri-ciri tertentu. Mereka merupakan golongan yang mudah marah-marah, melawan dan memberontak kerana melayan atau menahan emosi yang meronta hasil idealisme mereka. Kombinasi geram dan pendam sama ada dari segi mental atau fizikal merupakan sifat yang sering dikaitkan pada mahasiswa. Semua sikap dan sifat ini hasil tindak balas idealisme yang ada pada diri mereka untuk mencuba sesuatu yang baharu dan memperjuangkan sesuatu yang dirasakan tidak adil di dalam masyarakat dan juga komuniti mahasiswa. Oleh itu, mereka melakukan banyak aktiviti termasuk membuat demonstrasi, perarakan, mogok dan juga wacana.

Salah satu cara mahasiswa mendekati masyarakat dan membuat perubahan adalah melalui aktivisme dan kegiatan dalam gerakan mahasiswa. Muhammad Abu Bakar (1973) dan Weiss (2016) menggunakan istilah aktivisme kerana ia didorong oleh sikap mahasiswa yang menginginkan aktiviti berterusan dan bukan sekadar berkala untuk memenuhi syarat persatuan atau subjek tertentu sahaja. Ia berlawanan dengan tatacara kelulusan program mahasiswa masa kini yang memerlukan kelulusan dan menghadapi kesukaran birokrasi. Muhammad Abu Bakar (1973) dan Mohd Shuhaimi (1995) mengatakan aktivisme dan gerakan mahasiswa adalah hasil pengamatan dan tindak balas mahasiswa terhadap perkaraperkara dan isu-isu yang berlaku di sekitar mereka. Aktiviti itu ini didorong oleh semangat muda dan sifat mahasiswa yang tidak boleh duduk diam (Weiss 2016). Gerakan mahasiswa pula menurut Weiss (2016) terbentuk apabila mahasiswa berganding bahu dan bekerjasama sesama mereka untuk menggerakkan objektif perjuangan mereka sama ada berasaskan isu di dalam ataupun di luar kampus. Pelbagai aktiviti dan program sama ada berdaftar ataupun tidak telah diadakan untuk memenuhi keperluan tersebut. Oleh itu, aktivisme dan gerakan mahasiswa merupakan manifestasi mahasiswa terhadap pemahaman dan pengamalan pelajaran mereka seperti di dalam kuliah.

Aktiviti yang mereka lakukan itu hasil dan manifestasi dari corak berfikir dalam diri. Mereka tidak berfikiran takut atau gementar untuk menghadapi cabaran dan halangan yang ada untuk menggerakkan aktiviti kerana memenuhi kepuasan diri mereka menjalankannya sebagai golongan yang berdarah muda sesuai dengan kelompok umur mereka. Ia didorong sifat mereka yang mahu mencuba perkara baharu dan bersemangat mencuba kelainan. Kebebasan berfikir digunakan sepenuhnya oleh mereka merangka idea, ilmu, pengetahuan dan pergerakan untuk mencapai matlamat yang mereka persetujui bersama secara berkelompok dan mencuba perkara baharu. Shamsul Amri Baharuddin (2009) berpandangan mahasiswa secara individunya menggunakan potensi mereka sama ada fizikal dan mental untuk memenuhi kehendak gerakan mahasiswanya tanpa memikirkan keburukan atau kebaikan yang bakal menimpanya. Bagi mereka, yang penting adalah matlamat akhirnya mampu tercapai. Keberanian dan kesanggupan menjadi taruhan mereka dalam aktivisme. Artikel ini akan membincangkan tentang gerakan mahasiswa dan aktiviti mereka pasca merdeka sehingga dekad 80-an. Kebebasan berfikir menjadi tema yang ingin dibahaskan untuk menghuraikan corak kebebasan berfikir yang dilakukan oleh mahasiswa berserta faktor kecenderungannya.

\section{Kebebasan Berfikir Mahasiswa}

Berfikir dengan menggunakan akal yang waras merupakan aktiviti penting yang perlu ada dalam diri mahasiswa. Ia bersesuaian dengan peranan manusia untuk memakmurkan dan mentadbir alam selaras dengan kehendak Allah. Kegiatan berfikir juga perlu dimanfaatkan sebaik mungkin supaya kebaikannya dapat dirasai oleh semua orang. Lebih-lebih lagi sebagai seorang mahasiswa yang perlu juga memikirkan tentang keadaan kumpulan mereka dan juga permasalahan masyarakat. Wan Mohd Nor (2017) berpandangan apabila mahasiswa memberi khidmat kepada masyarakatnya membuktikan keberhasilan pengajiannya di universiti. Oleh sebab itu, aktiviti akal dan berfikir sangat penting dalam kehidupan dan 
diberikan kebebasan terutamanya dalam peringkat mahasiswa untuk menjadikan mereka sebagai golongan yang matang.

Mahasiswa juga mempunyai ruang imaginasi tersendiri yang hidup dengan pelbagai potensi yang boleh digilap dari segi mental, fizikal, emosi dan moral. Ia didorong oleh keupayaan berfikir, mencerna, membincangkan dan menjalankan idea-idea mereka. Ia secara tidak langsung mendorong mereka berfikiran terbuka dan terdedah kepada pelbagai idea, maklumat dan pengalaman lampau orang lain yang mereka perlukan untuk mengisi ruang imaginasi yang mereka miliki. Shamsul Amri Baharuddin (2007) mengatakan mereka gigih dan bersungguh-sungguh untuk mencapai idaman tersebut walaupun ada tentangan dan halangan. Oleh sebab itu, kebanyakan penyambung kepada sesebuah perjuangan fahaman atau ideologi diambil dalam kalangan mahasiswa yang dilatih dan diasuh. Apabila semangat mereka telah diisi dengan perjuangan mereka tidak lagi kisah untuk berasa malu dan janggal beraksi memperjuangkan pelbagai isu dan membentuk kelompok sosial mengikut ideologi yang dianuti.

Aktiviti berfikir juga boleh terbabas dengan dipengaruhi oleh unsur sekularisme dan pembaratan. Syed Muhammad Naquib Al-Attas (2011) menegaskan kebebasan dalam berfikir akan membuat manusia berfikir dengan memandang kepada Barat sebagai punca kemajuan melalui pembaratan dan tidak lagi memandang agama sebagai sumber cara hidup melalui pengaruh sekularisme. Mahasiswa yang menganuti kebebasan berfikir sedemikian akan mula menolak atau bersifat acuh tak acuh terhadap agama serta memandang rendah kepada jati diri, sejarah dan kebudayaan Melayu. Syed Muhammad Naquib Al-Attas (2011), Muhamad Faisal (2014) dan Zulkifli Ismail (2014) berpandangan kemunculan ideologi yang bertentangan dengan agama dan budaya cara hidup tempatan seperti sekularisme dan pembaratan apabila manusia berfikir tanpa bersandarkan kepada landasan yang jelas. Dalam hal ini, Mahasiswa juga mungkin terjerumus dalam kebebasan dalam berfikir.

Mahasiswa sangat bersemangat menerokai perkara-perkara baharu sekeliling mereka. Mereka juga sangat teruja dengan buah dan gaya pemikiran yang unik serta asing bagi orang lain untuk menunjukkan mereka lebih terkedepan dan berwibawa berbanding orang lain. Shamsul Amri Baharuddin (2007) mengatakan mereka sangat suka dengan idea-idea baharu dalam masa yang sama mudah terpengaruh dengan ideologi-ideologi asing yang mungkin bertentangan dengan norma yang diterima oleh masyarakat melalui agama dan budaya. Anasir-anasir ini akan mempengaruhi mahasiswa untuk melakukan aksi melawan dan mencabar pihak autoriti dan pihak berkuasa sebagai tanda tidak puas hati dan marah. Tindak balas dan respons mahasiswa hasil kebebasan dalam berfikir boleh dilihat dalam setiap dekad terutama dekad 70an. Kebebasan berfikir dalam kalangan mahasiswa telah mendorong mereka melakukan pelbagai bentuk tindakan sebagai tindak balas perkara-perkara yang berlaku dalam kalangan mereka dan juga masyarakat. Oleh sebab itu, kebanyakan organisasi atau persatuan yang menginginkan pembaharuan atau pelapis dan pembawa idea mereka akan mengambil kelompok mahasiswa ke dalam gerakan mereka sebagai penyambung perjuangan ideologi.

Berfikir memang dapat memberikan kebaikan kepada agama, sosial dan masyarakat. Malahan dengan berfikirlah kemajuan teknologi akan boleh dicapai yang dapat memberikan kemudahan dan idea baharu kepada manusia. Sidek Baba (2009) menegaskan bahawa berfikir sekiranya digunakan untuk Islam dan selaras dengan tuntutan tauhid akan membawa kebaikan yang banyak untuk umat dalam membina tamadun. Walau bagaimanapun, sekiranya ia disalahertikan dan disalahgunakan akan membawa ke jalan yang salah.

\section{Faktor Perangsang Kebebasan dalam Berfikir}

Faktor perangsang kebebasan berfikir merupakan faktor atau punca yang mempengaruhi gaya dan corak pemikiran, aktiviti dan tindakan mahasiswa. Terdapat empat faktor yang merangsang kebebasan berfikir mahasiswa iaitu sosioekonomi, dakwah, politik dan Akta Universiti dan Kolej Universiti (AUKU). 


\section{Sosioekonomi}

Keadaan sosioekonomi mahasiswa mempengaruhi cara dan corak berfikir. Mahasiswa yang datang dari keluarga yang mempunyai tahap sosioekonomi yang tinggi mempunyai tahap kewangan yang baik di samping mempunyai keterbukaan dalam pergaulan dan cara berfikir kerana menetap di bandar. Mahasiswa yang datang dari keluarga yang mempunyai tahap sosioekonomi yang rendah pula mempunyai tahap kewangan yang rendah dan tercari-cari dalam kehidupan kampus kerana kebanyakan mereka berasal dari kampung. Muhammad Abu Bakar (1973) dan Zainah Anwar (1990) menceritakan bagaimana suasana kehidupan asal mahasiswa di rumah mempengaruhi gaya dan corak kebebasan berfikir mahasiswa. Mahasiswa yang berasal dari golongan kaya dan elit akan menumpukan perhatian mereka kepada pengajian semata-mata. Ia berlainan dengan kelompok mahasiswa yang berasal dari golongan keluarga yang miskin dan susah yang merupakan majoriti dalam kalangan mahasiswa di kampus pada dekad ini. Kelompok mahasiswa ini juga bersifat lebih agresif, responsif, keras dan proaktif. Mereka akan sentiasa peka terhadap perkara yang melandai sekeliling mereka dan juga masyarakat.

Sosioekonomi yang rendah seumpama kemiskinan mencorakkan mahasiswa lebih kreatif memikirkan cara mengubah masyarakat. Mereka akan menggembleng idea dan sangat cakna dengan keperitan hidup masyarakat dalam kepompong kemiskinan. Ia mengakibatkan mahasiswa ditekan dan mereka terpaksa memikirkan jalan keluar dari kepompong kemiskinan. Muhammad Abu Bakar (1973) dan Weiss (2016) menggambarkan mereka rela bersusah payah dengan masyarakat kampung dengan membela nasib mereka. Pelbagai usaha digerakkan sama ada dengan protes dan juga bersama-sama menyelami hati masyarakat dengan mengadakan program bersama mereka. Mereka telah mencadangkan kepada kerajaan untuk diubah serba sedikit sistem pendidikan yang menguntungkan mereka dalam masa yang memperbanyakkan lagi peluang-peluang pekerjaan. Ibrahim Saad (1986); Ungku A. Aziz (1987) berpandangan tahap pendidikan tinggi dan peluang-peluang pekerjaan yang banyak mampu mengeluarkan mahasiswa untuk keluar daripada kepompong kebiasaan.

Taraf sosioekonomi yang rendah mendesak kebebasan berfikir mahasiswa untuk tekun dalam menimba ilmu. Ibrahim Saad (1986) menggambarkan pelajaran dianggap oleh orang Melayu sebagai jalan untuk mencapai kejayaan dan keluar dari taraf kemiskinan. Kebanyakan mereka menuntut supaya pihak penguasa bersikap adil dan saksama terhadap golongan yang sekelompok dengan mereka kerana ada yang keciciran akibat tidak nampak peluang masa depan dan tiada harta untuk menghantar anak belajar ke pengajian tinggi di samping menyediakan biasiswa pelajaran. Ibrahim Saad (1986) juga mengatakan taraf sosial masyarakat Melayu yang rendah menyebabkan mereka tidak memahami bahasa lain kecuali bahasa Melayu walaupun minat terhadap ilmu. Apabila mereka mulai masuk ke alam siswazah, keyakinan mereka mulai bertambah untuk belajar bahasa Inggeris. Ibrahim Saad (1986) mengatakan mereka berasa untuk menjadi setanding dan sama taraf dengan siswazah-siswazah bukan bumiputera yang lain.

\section{Dakwah dan Kebangkitan Islam}

Dakwah merupakan suatu usaha mengajak manusia ke jalan yang benar dan diredai Allah. Tuntutan menjalankan usaha dakwah ini hasil dari tuntutan tauhid yang menjelaskan bahawa semua manusia perlu beriman kepada Allah. Orang yang tidak beriman kepada Allah perlu diajak untuk beriman kerana Allah adalah satu-satunya tuhan yang wajib dipercayai. Chandra Muzaffar (1988) dan Zainah Anwar (1990) mengatakan pemikiran ini menjadi teras kepada pemikiran orang Islam yang mahukan seluruh kehidupan di dunia ini berlandaskan kepada cara hidup yang ditetapkan oleh Allah. Pemikiran dakwah yang berteraskan kepada tauhid ini telah merangsang kepada kewujudan gerakan mengajak manusia meninggalkan pemikiran karut, kepercayaan khurafat dan agama selain Islam. Saifuddin Abdullah (2009) berpandangan usaha dakwah ini telah disambut oleh mahasiswa yang belajar di luar negara setelah mereka 
pulang ke Tanah Melayu seperti Syeikh Tahir Jalaluddin, Syed Sheikh al-Hadi, Syed Salim al-Kalali dan Abas Mohamad yang pulang dari menuntut di Timur Tengah. Mereka dipengaruhi pemikiran Syed Jamaluddin alAfghani dan Muhamad Abduh yang telah memulakan gerakan keilmuan umat Islam ke arah pembangunan sosioekonomi dan menggerakkan gerakan reformis-agama yang terawal dalam pendidikan, sosial dan juga ekonomi Islam. Mereka telah mencetuskan gerakan kebangkitan Islam di Tanah Melayu untuk memberi kesedaran kepada orang Islam agar menentang penjajah.

Inti sari penting kepada gerakan pembebasan ini ialah mewujudkan negara Islam yang merdeka dengan acuan Islam. Hal ini telah diteruskan sebelum 1957 lagi dan usaha ini diteruskan hingga pada masa kini. Sebelum merdeka, usaha tertumpu untuk mencapai kemerdekaan, manakala selepas merdeka usaha tertumpu pula kepada usaha merubah kerangka Perlembagaan kepada menjadi negara Islam. Namun, sejak mutakhir ini rentak perjuangan negara Islam menurut Riduan Mohamad Nor (2012) tertumpu pula kepada pengisian kepada negara Islam kerana hasil usaha sebelum ini yang dilihat semakin positif kepada negara Islam dan perlu realistik dengan suasana Malaysia yang berbilang agama dan bangsa. Dalam masa yang sama Malaysia dari segi perlembagaannya diakui sebagai negara Islam berdasarkan Perkara 3 Perlembagaan Persekutuan. Walaupun mungkin rentak perjalanan usaha menubuhkan negara Islam ini berbeza antara dahulu dan sekarang, tetapi matlamat mereka adalah satu. Mahasiswa merupakan kumpulan yang menyumbang kepada gerakan ini bermula seawal dekad 60-an selepas zaman kemerdekaan.

Dakwah telah membangkitkan keinsafan dalam kalangan mahasiswa daripada hidup dengan cara Barat dan tidak mengikut landasan agama kepada mematuhi ajaran agama dan menjaga batas-batasnya. Kebangkitan semula Islam di Malaysia juga menurut Chandra Muzaffar (1988) ialah usaha menegakkan semula Islam, institusi-institusi Islam, undang-undang Islam dan Islam keseluruhannya. Manifestasi dakwah dan kebangkitan Islam di Malaysia dilihat dengan kebanyakan lelaki dan perempuan berpakaian yang sopan dan menutup aurat. Pergaulan mereka lebih terjaga. Chandra Muzaffar (1988) mengatakan ianya ditonjolkan melalui penggunaan ungkapan-ungkapan Islam dalam bahasa Arab, penjagaan kehalalan makanan dan menolak hiburan keterlaluan. Pita-pita kaset mengenai Islam juga laris dijual hasil pembelian dalam jumlah yang besar dalam kalangan muda-mudi dan juga masyarakat awam. Dakwah disambut baik oleh golongan mahasiswa sehingga wujudnya gelombang dakwah di dalam kampus ketika itu. Zainah Anwar (1990) mengatakan ia merupakan percubaan dan desakan mewujudkan semula Islam sebagai budaya dan juga sebagai sistem sosial yang baharu.

Cubaan untuk menggerakkan suatu sistem sosial baharu berdasarkan Islam juga berlaku dalam kalangan mahasiswa melalui dakwah. Antara aktivis mahasiswa yang menggerakkan dakwah Islam dalam kalangan mahasiswa adalah Anwar Ibrahim. Beliau ketika itu memegang jawatan sebagai presiden PKPIM. Zainah Anwar (1990) dan Siti Hamisah (2009) berpandangan kredibiliti dan pengetahuan beliau dalam kepimpinan dan agama Islam menaikkan namanya sebagai pemimpin pelajar Islam. Dengan bakat dan sokongan yang beliau terima menyemarakkan lagi perjuangan Islamisasi di kalangan mahasiswa. Kebangkitan Islam muncul melalui usaha-usaha dakwah belia di Malaysia. Ia digerakkan oleh usaha-usaha islah mengingatkan dan menggesa masyarakat bahawa Islam sebagai suatu cara hidup. Zainah Anwar (1990) mengatakan dakwah sangat berpengaruh sehinggakan mampu membentuk gelombang mahasiswa yang mahukan perubahan dalam hidup. Makna dakwah juga telah cuba disebatikan dalam hidup mahasiswa di mana mereka mahukan supaya kerajaan berubah dengan mengangkat Al-Quran dan Al-Sunnah sebagai perlembagaan negara dan menyahkan undang-undang kafir daripada anutan politik di dalam negara Malaysia. Dakwah mendidik mahasiswa untuk menerapkan nilai-nilai Islam dalam pemikiran mereka dan dibawa dalam kegiatan gerakan mahasiswa termasuk dalam politik nasional dan juga politik kampus. 
Situasi dan keadaan politik sesebuah negara memberikan kesan kepada masyarakat keseluruhannya. Kemelut dan keputusan politik semasa berkait rapat dengan cita rasa golongan muda. Mereka merupakan golongan majoriti pengundi yang membentuk pilihan mereka berdasarkan isu dan keperluan yang mereka ingin ketengahkan yang bersangkut paut dengan kehidupan mereka seperti kos sara hidup dan hutang pinjaman pelajaran. Golongan muda ini juga menurut Ummi Munirah Syuhada et al. (2016) mempunyai pengaruh yang kuat dalam pembentukan politik di mana suara mereka akan didengari sekiranya mereka betul-betul cakna dan sensitif terhadap isu politik di sekeliling mereka. Pengaruh ini juga ada pada mahasiswa yang mengambil berat tentang permasalahan dihadapi mereka.

Politik merangsang berfikir dalam kalangan mahasiswa menerusi refleksi terhadap dasar, polisi dan program yang dirancang dan yang dilaksanakan oleh kerajaan. Mahasiswa yang aktif dan kritis akan mengambil cakna terhadap semua ini kerana mereka merupakan golongan yang berpendidikan. Perkara ini dapat dilihat dengan jelas menerusi siri kebangkitan pelajar pada era 60an dan 70an di mana pada ketika itu mereka merupakan kumpulan yang mendesak kerajaan untuk mengiktiraf Bahasa Melayu sebagai Bahasa Kebangsaan. Junaidi Abu Bakar (1993) berpandangan mahasiswa bertindak sebagai agen pendesak yang berperanan sebagai pengimbang dalam sesebuah kerajaan. Sebahagian keputusan politik kerajaan ada yang dinilai semula hasil tuntutan mahasiswa. Kesedaran mahasiswa terhadap politik juga sangat memainkan peranan dalam situasi politik termasuklah dalam isu luar negara. Mohd Shuhaimi (1995) mengatakan mahasiswa bergiat aktif memberi respons dan tindak balas terhadap politik luar melalui kegiatan politik kampus bagi menunjukkan sokongan atau bantahan. Aktiviti yang mereka lakukan ini dibuat di dalam dan luar kampus dan juga pilihanraya kampus berasaskan parti dan kumpulan masingmasing. Parti yang bertanding di dalam pilihanraya kampus mewakili parti-parti besar yang bertanding dalam pilihanraya umum di peringkat nasional.

Maklumat tentang politik juga menjadi punca keaktifan dan keagresifan mahasiswa dalam kebebasan berfikir. Ia menjadi pemangkin kepada mahasiswa untuk menyokong atau membangkang isuisu politik yang ditimbulkan. Mereka juga memikirkan tentang idea-idea yang berlawanan dengan keputusan politik yang dibuat kerajaan. Muhammad Abu Bakar (1973) dan Junaidi Abu Bakar (1993) menceritakan bahawa setiap daripada peristiwa protes, bantahan dan demonstrasi mahasiswa ketika itu merupakan reaksi kepada keputusan politik yang berlaku di zaman dan era masing-masing. Ia juga menjadi suatu faktor yang relevan sehingga kini. Weiss (2016) berpandangan politik sangat berpengaruh dalam mencorakkan aktivisme mahasiswa. Mahasiswa kini tidak terlepas daripada pengaruh politik kerana sifat politik itu yang berubah-ubah dan mengikut suasananya sendiri. Permasalahan isu politik mempengaruhi mahasiswa untuk mencari jalan penyelesaian secara kolektif. Mazli et al. (2015) mengatakan mereka akan membuat protes dan mogok pada perkara politik yang ada kaitan dengan diri mereka seperti isu agama dan kaum. Mereka akan berbincang, berbahas, berbalah secara berterusan sehinggalah isu-isu itu selesai.

\section{Akta Universiti dan Kolej Universiti}

Akta Universiti dan Kolej Universiti 1971 (AUKU) diperkenalkan oleh kerajaan sebagai panduan yang mengawal struktur pentadbiran universiti dan kegiatan pelajar. Ia juga memberikan kuasa kepada menteri dan kerajaan untuk mengawal pentadbiran universiti dan perjalanannya. Oleh itu, AUKU boleh dianggap sebagai cara kerajaan mengawal selia perjalanan universiti dan melicinkan pentadbirannya. Dalam masa yang sama, ia mempunyai beberapa peruntukan yang menyekat kebebasan mahasiswa dalam beraktiviti seperti kemestian mendapatkan keizinan pihak pentadbiran untuk melakukan program. Isi-isi seksyen AUKU menurut Saifuddin Abdullah (2009) seperti melarang mahasiswa atau pertubuhan mahasiswa 
daripada memanggil, berhimpun atau mengorganisasikan perhimpunan seramai lebih dari lima orang tanpa terlebih dahulu mendapat kebenaran bertulis dari Naib Canselor atau wakilnya.

Mahasiswa juga tidak boleh menyertai mana-mana perhimpunan yang diadakan kecuali mendapat kebenaran dari Naib Canselor atau orang yang diberi kuasa olehnya. Selain itu, mahasiswa, pertubuhan, badan atau kumpulan mahasiswa tidak dibenarkan mempunyai atau mengguna pembesar suara atau seumpamanya. Muhammad Nur Anuar (1986), Junaidi Abu Bakar (1993) dan Saifuddin Abdullah (2009) mengatakan AUKU juga melarang mahasiswa atau pertubuhan mahasiswa daripada menjalankan sebarang aktiviti di luar kampus kecuali dengan kebenaran bertulis Naib Canselor. Ia termasuklah melarang mahasiswa dari mengambil bahagian dalam apa-apa perniagaan, pekerjaan atau aktiviti lain secara sepenuh masa atau sambilan yang menurut Naib Canselor adalah tidak diingini.

Larangan juga terhadap mahasiswa dan pertubuhan mahasiswa daripada menjadi ahli atau bersekutu dengan mana-mana persatuan, parti politik, kesatuan sekerja dan lain-lain kecuali sebagaimana diperuntukkan di bawah Perlembagaan Universiti atau diluluskan terlebih dahulu secara bertulis oleh Naib Canselor. Bukan setakat itu sahaja, AUKU juga melarang mahasiswa dan pertubuhan mahasiswa daripada menyatakan sokongan, simpati atau bangkangan terhadap mana-mana parti politik, kesatuan sekerja dan badan-badan lain. Sekiranya seseorang mahasiswa tidak mematuhi atau melanggar sesuatu arahan atau kehendak yang sah diberi atau dibuat oleh mana-mana pegawai atau pekerja universiti yang diberi kuasa untuk memberi atau membuatnya dalam kampus maka mahasiswa itu adalah bersalah atas kesalahan tatatertib. Pemegang jawatan atau orang yang menguruskan kumpulan mahasiswa adalah disifatkan melakukan kesalahan sekiranya kesalahan dilakukan atas nama atau bagi pihak persatuan atau kumpulan mahasiswa itu, melainkan dapat dibuktikan bahawa kesalahan itu dilakukan tanpa pengetahuannya dan mereka telah berusaha mencegah kesalahan itu. Mereka boleh didakwa atas kesalahan itu walaupun mereka tidak mengambil bahagian dalam melakukan kesalahan itu.

AUKU mengakibatkan sebahagian mereka ketakutan menyatakan suara dan apa yang mereka fikirkan tidak boleh dimanifestasikan seperti sebelum kewujudan AUKU lagi. Mereka juga lebih berhati-hati dalam mengimplementasikan idea-idea fikiran mereka di dalam program dan aktiviti Jika dibenarkan pun hanya perlu mengikut piawaian yang ditetapkan. Pengurusan universiti dan kegiatan pelajar terikat dengan AUKU. Muhammad Nur Anuar (1986) dan Mohd Shuhaimi (1995) menyifatkan perlaksanaan AUKU kepada permulaan era kejatuhan kepada kegemilangan kegiatan mahasiswa. AUKU pada akhirnya memberikan kesan dalam perjalanan sebuah universiti dan aktivisme mahasiswa. Junaidi Abu Bakar (1993) mengatakan ianya telah mengubah tatacara persatuan pelajar, bahagian hal ehwal pelajar dan penyertaan pelajar dalam politik. Ia juga membentuk kegiatan pelajar hanya tertumpu di dalam kampus dan mengakibatkan perpecahan pelajar dengan lambakan persatuan berdaftar dan juga pembubaran Persatuan Kebangsaan Pelajar Malaysia (PKPM). AUKU sangat berpengaruh melalui seksyen-seksyennya dalam peraturan yang memberi kesan terhadap mahasiswa. Oleh itu, ia mengakibatkan mahasiswa agak berhati-hati dalam gerakan mereka dalam masa yang sama menguatkan lagi gerakan mereka terhadap isu-isu yang dibawa.

AUKU walaupun pada zahirnya menyekat mahasiswa namun sejarah menunjukkan ia merangsang kebebasan berfikir untuk terus menerus menyatakan pandangan dan menjalankan aktivisme mereka dalam kekangan yang ada. Saifuddin Abdullah (2009) menyatakan jiwa mereka yang disekat melalui undangundang sebenarnya menolak mereka untuk lebih aktif bebas berfikir dan menjalankan kegiatan sebagai seorang mahasiswa. AUKU telah mempengaruhi mahasiswa untuk berfikiran lebih bebas dalam beraktiviti dan tidak terkongkong dalam bilik kuliah dan peraturan pentadbiran semata-mata walaupun dikongkong dengan akta rasmi. 


\section{Kebebasan Berfikir Mahasiswa Dekad 1970-an}

Dalam perbincangan seterusnya, artikel ini akan membincangkan kegiatan-kegiatan mahasiswa yang didorong oleh faktor kebebasan berfikir seperti sosioekonomi, dakwah, politik dan juga AUKU. Ianya membahaskan bagaimana faktor ini berfungsi dalam dekad ini. Dekad ini merupakan dekad kelahiran semula Malaysia. Peristiwa 13 Mei 1969 yang menimpa sebelum ini telah mengajar rakyat Malaysia untuk hidup saling hormat-menghormati dan bersikap sederhana di bawah Perlembagaan Persekutuan dan Kontrak Sosial. Selepas pengunduran Tunku Abdul Rahman, Tun Abdul Razak telah mengambil alih jawatan beliau sebagai Perdana Menteri. Beliau melihat kepada usaha-usaha untuk pembasmian kemiskinan secara menyeluruh dalam masa yang sama meningkatkan nilai ekonomi orang Melayu di mana ketika itu menurut Jabatan Perangkaan Malaysia (2014; 2016; 2017), bumiputera hanya menguasai 4.3 peratus jumlah pemilikan harta, bukan bumiputera sebanyak 34 peratus dan warga asing sebanyak 61.7 peratus ketika itu. Masyarakat Melayu ketika itu lebih terarah kepada pekerjaan perusahaan pertanian sebanyak 67.6, perlombongan sebanyak 32.1 peratus dan perniagaan, pentadbiran awam dan pertahanan sebanyak 42.6 peratus. Dasar Ekonomi Baru (DEB) telah diperkenalkan dengan matlamat utama dasar ini bagi mewujudkan perpaduan negara dengan mengurangkan perbezaan ekonomi, sosial, kebudayaan dan penempatan. Kerajaan berusaha untuk mengurangkan dan seterusnya membasmi kemiskinan dengan memperbanyakkan peluang-peluang pekerjaan kepada semua rakyat tanpa mengira kaum dalam masa yang sama menyusun semula masyarakat untuk mengurangkan dan seterusnya menghapuskan pengenalan kaum mengikut fungsi-fungsi ekonomi.

\section{Sosioekonomi}

Sosioekonomi negara ketika ini amat membimbangkan. Selepas peristiwa 13 Mei 1969, isu sosioekonomi tetap menjadi fokus utama dalam aktivisme mahasiswa. Siti Hamisah (2009) berpandangan isu sosioekonomi masyarakat telah dirasionalisasikan oleh Anwar Ibrahim dengan kebangkitan semula Islam yang mula mendapat tempat dalam kalangan mahasiswa. Ianya juga menjadi perkara yang diperjuangkan oleh mahasiswa dakwah. Dekad 1970-an menunjukkan taburan penduduk Malaysia pada tahap 73.1 peratus di luar bandar manakala minoriti penduduk sebanyak 26.9 peratus menetap di kawasan bandar. Kemiskinan rakyat Malaysia mengikut Jabatan Perangkaan Malaysia $(2014 ; 2016$; 2017) ketika itu masih tinggi iaitu 49.3 peratus. 58.6 peratus kemiskinan berlaku di kampung dan 24.6 peratus berlaku di bandar. Pendapatan kasar bulanan isi rumah purata juga sangat rendah. Ia merekodkan RM428 isi pendapatan purata di bandar dan RM200 di kampung. Kedua-duanya dapatan bagi tahun 1970. Tahun 1979 pula menunjukkan peningkatan di mana RM1045 bagi penduduk bandar dan RM523 bagi penduduk di kampung.

Sosioekonomi dekad ini mempengaruhi mahasiswa untuk belajar dengan bersungguh-sungguh mengubah nasib diri. Dasar Ekonomi Baru pula diperkenalkan oleh Tun Abdul Razak untuk mengimbangkan ekonomi antara kaum melalui pendidikan. Hasil DEB juga ramai anak-anak Melayu dihantar belajar di luar negara. Zainah Anwar (1990) berpandangan ia mempengaruhi fikiran mahasiswa untuk mencari jalan supaya dapat keluar daripada kekangan kemiskinan dan kemunduran ini pada masa hadapan hasil bantuan dan sokongan daripada kerajaan. Ramai anak-anak Melayu berasal dari kampung, desa dan pinggir bandar diterima belajar di universiti. Mereka mulai menyedari tanggungjawab mereka untuk membawa perubahan kepada masyarakat mereka nanti.

Mahasiswa mula mengambil langkah drastik dengan turun ke lapangan. Mahasiswa melalui Persatuan Mahasiswa Universiti Malaya (PMUM) mula menganjurkan Projek Perkhidmatan Masyarakat. Dengan perbelanjaan sebanyak RM 8 000, 40 orang mahasiswa telah pergi ke empat buah kampung iaitu Pulau Kundur di Kota Bharu, Manek Urai di Kuala Krai, Gaong di Kuala Berang dan Chalok di Terengganu. 
Muhammad Abu Bakar (1973) mengatakan objektif projek ini ialah untuk memahami masalah yang dihadapi penduduk desa dan membantu mereka menyelesaikan masalah itu selain pelajaran di kuliah.

Mereka juga menyedari pelajaran sebagai sistem untuk menambahbaik masyarakat. Isu penaiktarafan UiTM sebagai pusat pengajian tinggi rakyat juga menjadi tumpuan. UiTM yang sebelum ini dikenali sebagai ITM telah didesak oleh pelajar-pelajarnya supaya diberikan taraf universiti penuh. Tuntutan juga dibuat untuk menaiktaraf sebahagian sijil diploma kepada ijazah. Ia kerana kepayahan mahasiswa keluaran ITM untuk mendapatkan kerja dengan sijil diploma yang mereka ada. Ibrahim Ali (2016) yang juga presiden pelajar ketika itu menceritakan bagaimana mahasiswa telah merancang untuk membuat himpunan mega di Bangunan Parlimen. Walau bagaimanapun, sebahagian besar telah ditangkap semasa perarakan mereka dari UiTM Shah Alam ke Parlimen. Sebahagian pelajar yang berada di dalam UiTM memberontak dan menguasai bangunan pentadbiran. Rampasan kuasa telah berlaku sehinggalah berlaku perbincangan pimpinan pelajar dengan Tun Abdul Razak. Selepas itu, barulah rampasan kuasa dan mogok itu selesai.

Mahasiswa juga mengadakan himpunan besar-besaran iaitu Peristiwa Baling 1974. Ia dikatakan berpunca daripada kematian beberapa penoreh getah yang kebuluran akibat jatuhnya harga pasaran getah. Weiss (2016) dan Ibrahim Ali (2016) mengatakan kejadian itu menyebabkan ramai aktivis mahasiswa yang ditangkap dan dihumban ke dalam ISA. Peristiwa ini terjadi selepas penguatkuasaan AUKU 1971. Ia merupakan sebuah demonstrasi besar-besaran dalam sejarah gerakan mahasiswa Malaysia iaitu Peristiwa Baling. Pada 19 November 1974, lebih 1,000 orang petani yang miskin di Baling mula mengadakan demonstrasi dan perarakan lapar kerana membantah kenaikan harga barang keperluan harian dan kejatuhan harga getah. Pada 21 November, jumlahnya menjadi lebih 13,000 orang dan menjadi 30,000 pada 1 Disember. Selepas mengetahui demonstrasi masyarakat Baling ini, seramai 5,000 orang mahasiswa mengadakan demonstrasi pada 3 Disember di Kuala Lumpur sebagai menyokong nasib mereka dan mendesak kerajaan supaya dengan segera menyelesaikan masalah inflasi dengan menaikkan harga getah ke tahap yang munasabah. Ia bermula tercetus di Universiti Malaya kemudian berjangkit ke ITM, UKM, USM dan Politeknik Ungku Omar. Seramai 1,128 orang mahasiswa telah ditahan di mana Anwar Ibrahim telah ditahan ISA dan Hishamuddin Rais lari ke luar negara. Sosioekonomi juga mempengaruhi persekitaran mahasiswa selepas peristiwa 1969. Pendidikan dilihat sebagai pengimbang dalam kemajuan sosioekonomi yang dipegang oleh kaum Cina dan tuntutan menaiktarafkan UiTM membuktikan pemerkasaan mahasiswa bumiputera.

\section{Dakwah dan Kebangkitan Islam}

Dakwah ketika ini mengalami fasa kebangkitan semula Islam. Ia bukanlah bermakna Islam baru disebarkan tetapi penerapan semula pemahaman Islam yang sebenar meliputi corak dan gaya kehidupan. Kebangkitan semula Islam ini menurut Chandra Muzaffar (1986) disebabkan pengaruh untuk mengangkat semula Islam ke tempat yang selayaknya sebagai agama persekutuan.

Dakwah mendorong mahasiswa memandang kepada Islam sebagai asas panduan kebebasan berfikir mereka. Zainah Anwar (1990) mengatakan sebahagian pelajar ketika itu mulai sedar peranan Islam dalam kehidupan dan menganggap Islam adalah suatu penyelesaian yang harus dipraktikkan dan mereka berasa menyesal tidak menggunakan Islam sebelum ini. Peristiwa 13 Mei 1969 juga menurut Zainah Anwar (1990), merupakan pencetus kepada kesedaran memperjuangkan Islam dan asas budaya Melayu sebagai tunjang utama. Ketika itu juga masyarakat mula melihat bangsa Melayu sebagai ummah yang perlu diselamatkan hidup matinya, bahasanya, pendidikan dalam Bahasa Melayu dan mengangkat Islam sebagai landasan. Anwar mula merasionalisasikan tema perjuangan keadilan sosioekonomi dengan nilai-nilai Islam. 
Faktor kebangkitan Islam juga disebabkan hubungan pelajar Malaysia dan Indonesia melalui Himpunan Mahasiswa Islam Indonesia (HMI) dari segi pembelajaran pengurusan dan juga kesusasteraan yang mana sastera dan buku ajaran dan tafsiran Islam dari Indonesia di pandang tinggi atas semangat seMelayu. Zainah Anwar (1990) mengatakan pada 1971, Seorang pensyarah Institut Teknologi Bandung, Imaduddin Abdul Rahim yang mengajar di UTM juga memainkan peranannya sebagai pengajar bagi kumpulan-kumpulan pelajar. Ucapan agama menghidupkan jiwa pelajar untuk memperjuangkan dan mengamalkan Islam. Kebangkitan Islam melalui gerakan-gerakan dakwah juga menjadi tempat mahasiswamahasiswa berasal dari kampung dan desa untuk berpaut dan menumpang hal kebajikan. Mohd Shuhaimi (1995) mengatakan ketegangan itu juga telah mengakibatkan mahasiswa agak tegang antara kaum di dalam kampus akibat perarakan anti-Tunku dan perlaksanaan Bahasa Melayu di kampus. Pada masa ini juga ramai mahasiswa asal dari desa yang mula masuk universiti. Islam mula dianggap oleh pelajar sebagai suatu penyelesaian mutlak kepada masalah masyarakat. Charles Allers (2017) mengatakan dekad 70-an memperlihatkan bahawa kemasukan ramai anak orang Melayu ke universiti dalam masa yang sama mereka menganggap Islam sebagai penyelesaian mutlak kepada cabaran-cabaran hidup mereka.

Dakwah juga mengalihkan mahasiswa daripada ideologi nasionalisme dan sosialisme serta ideologi Barat kepada Islam. Ia juga disebabkan sokongan yang ramai diterima oleh penggerak dakwah dalam kalangan mahasiswa. Zainah Anwar (1990) mengatakan ramai pelajar berlatarbelakang keluarga miskin dan sederhana yang menyertai gerakan dakwah di kampus. Ini kerana mereka tidak menemui persatuan yang kena dengan jiwa kampung dan sederhana mereka melainkan gerakan dakwah. Mereka juga merasakan gerakan dakwah inilah yang akan membela nasib mereka yang terpinggir. Golongan ini yang kemudiannya memainkan peranan penting dengan menggerakkan kesedaran keperluan kemajuan di bawa juga ke kampung dan dirasai juga ahli masyarakat desa mereka. Kebangkitan Islam juga dapat dilihat di UiTM - dahulu dikenali sebagai ITM - pada dekad itu. Ketika itu juga masih terdapat sisa-sisa pemikiran ditinggalkan oleh penjajah seperti liberalisme dan sosialisme. Ibrahim Ali (2016) menggambarkan UiTM ketika itu dilanda isu sosial yang agak teruk dan pelajarnya ada yang memperjuangkan liberalisme, sosialisme serta fahaman lain yang bertentangan dengan adat ketimuran. Pelajarnya juga terlibat dengan aktiviti tari-menari dan minuman keras di mana hampir setiap minggu ada majlis tari-menari. Ada juga pihak luar seperti tentera akan mengambil pelajar ITM untuk dijadikan teman mereka di majlis yang diadakan di luar.

Walau bagaimanapun, pihak pentadbiran tidak mempedulikan soal moral pelajar dan selalu dilawan oleh Kesatuan Siswa ITM (KSITM) yang dikuasai pimpinan berminda agama dan suka bertelagah dengan pentadbiran menegakkan hal agama. Islamisasi juga turut berlaku di ITM di mana presiden pelajarnya, Ibrahim Ali menggalakkan nilai-nilai dan aktiviti berunsur Islam seperti pemeriksaan bilik untuk mendisiplinkan pelajar yang terlibat dengan gaya hidup barat dan tingkah laku berdosa. Ia dikatakan hasil pengaruh kemasukan PAS dalam kerajaan yang mula menggerakkan Islamisasi sebagai suatu usaha penting dalam kerajaan. PMIUM yang terkenal dengan agenda Islamnya telah mengubah kaedah perjuangannya yang agresif kepada usaha peningkatan kualiti peribadi yang selaras dengan Islam dan trend kebangkitan Islam di seluruh dunia pada masa itu. Orientasi dakwah Islamiah yang mengambil tempat dan kepemimpinan pelajar ketika itu telah memberi nafas baru kepada gerakan mahasiswa. Awal 70-an juga memperlihatkan kegiatan dakwah semakin berkembang dalam kalangan mahasiswa dan pendefinisian aspek tingkah laku, tatacara pakaian dan pelbagai aktiviti organisasi yang berkaitan Islam juga diperkenalkan. Ini termasuklah kegiatan dakwah tarbiah pelajar di mana isu-isu moral, majlis tari-menari dan parti Halloween dihalang manakala minggu orientasi diperkenalkan semula dengan mewajibkan kehadiran subuh dan berpakaian solat. PMUKM yang ketika itu baru diwujudkan telah diisytiharkan oleh presidennya Abdul Halim Arshat menerima Islam sebagai dasar dan matlamat perjuangannya sebelum pelajarnya telah terbahagi kepada dua aliran iaitu nasionalis dan Islamis pada awal 80-an. 
Kebebasan berfikir mahasiswa melalui dakwah juga telah memperkenalkan ABIM sebagai platform mereka. ABIM mula wujud pada 1971. Badlihisham (2015) mengatakan ABIM pada awal kewujudannya dipengaruhi oleh Ikhwan Al-Muslimin dan Jamaat Islami. Kerja dan usaha dakwah berterusan PMIUM, PKPIM dan PBMUM yang diketuai oleh Anwar Ibrahim yang juga penggerak kepada agenda kebangkitan Islam di kalangan pelajar telah melahirkan lepasan-lepasan universiti yang berkualiti. Zainah Anwar (1990) berpandangan akhirnya usaha dakwah selepas mereka ini membentuk Angkatan Belia Islam Malaysia (ABIM) bagi merancakkan lagi usaha dakwah dalam masyarakat. Jika sebelum ini Gerakan Kempen Kesedaran (GKK), sekarang seumpama program bakti siswa diadakan lebih untuk mengetahui keadaan sosial dan ekonomi semata-mata manakala dekad 1970-an menyaksikan bagaimana elemen-elemen dakwah juga dimasukkan juga ke dalam program seperti solat berjemaah dan ceramah agama. Kebangkitan Islam ketika itu juga membawa mesej nasionalisme untuk memperkuat kembali masyarakat Melayu selepas peristiwa 13 Mei 1969.

Dakwah ketika juga dipergiat untuk membanteras majlis tari-menari dan juga pergaulan bebas dalam kalangan mahasiswa. ABIM menggunakan rangkaian pelajar iaitu usrah untuk memperkukuh kedudukan mereka di samping memberi kefahaman Islam. Kebangkitan Islam di Malaysia tertumpu dalam kalangan belia yang datang dari keluarga mahasiswa kelas pertengahan dan bawahan. Mereka mengikut kepimpinan dalam kampus mereka. Ketika itu Anwar mahukan PMUM diletakkan di bawah kumpulan Islam dan perjuangannya di atas landasan Islam. Melalui PBMUM dan PMIUM di bawah Anwar ketika itu, mereka membentuk gerakan pembentukan haluan baharu kegiatan mahasiswa beracuan Islam yang mana akhlak menjadi isu yang utama. Islamis-Nasionalis juga berkembang ketika itu dengan menganjurkan seminar, syarahan, forum dan projek masyarakat supaya lebih mengambil berat tentang hasrat rakyat tetapi atas nama Islam. Dalam masa yang sama wujudnya gesaan terhadap kerajaan untuk menubuhkan kerajaan Islam berpandukan Quran Sunnah dan menganggap kerajaan sedia ada adalah kerajaan kafir dan wajib ditentang.

\section{Politik}

Politik dekad ini amat rumit. Ia kerana peristiwa 13 Mei 1969 juga turut terkesan ke atas corak politik nasional. Weiss (2016) mengatakan kerajaan baharu bersifat pelbagai parti dibentuk untuk menjamin perpaduan pada 1974. Kemasukan PAS ke dalam kerajaan telah memberi peluang kepada PAS untuk menjalankan usaha Islam di dalam kerajaan. ABIM ketika itu bertindak sebagai agen semak dan seimbang terhadap kerajaan bagi agenda Islam, pembanteras rasuah dan isu kemiskinan. Menurut Ridhuan Mohamad Nor (2012), transisi gagasan ideologi Islam telah secara perlahan-lahan mengambil alih pengaruh sosialisme dan nasionalisme di kampus-kampus universiti. Kemasukan PAS ke dalam kerajaan dan memegang jawatan-jawatan penting yang membawa agenda Islamisasi diperkenalkan. Ia turut mempengaruhi agenda Islamisasi dalam gerakan mahasiswa. Ketika itu juga, PERKIM, YADIM, Bank Islam dan Maktab Perguruan Islam mula ditubuhkan. Walau bagaimanapun, pengeluaran PAS dari Barisan Nasional pada 1977 juga memberi kesan kepada mahasiswa di mana menurut Zainah Anwar (1990) ramai yang beransur-ansur cenderung kepada kumpulan Pro-PAS.

Politik memberi kesan terhadap perjuangan bahasa kebangsaan dalam kalangan mahasiswa. Pada 1970, telah tertubuhnya sebuah universiti atas semangat Bahasa Kebangsaan iaitu UKM yang diperjuangkan oleh golongan mahasiswa pada 1968. Kewujudan UKM pada 1970 telah meredakan kebimbangan mahasiswa terhadap penggunaan Bahasa Melayu dalam pendidikan. Pada 7 Julai 1970 pula Demonstrasi Abdul Rahman Yaakob telah dilakukan oleh PBMUM dan disertai juga mahasiswa UKM yang mendesak beliau tidak meletakkan jawatan untuk memegang jawatan Ketua Menteri Sarawak. Ini kerana jasa beliau yang banyak dalam mempertahankan Dasar Pelajaran Dan Bahasa Kebangsaan sehingga lahirnya UKM. Beliau memberi jaminan dasar ini tetap terpelihara semasa dialognya di Dewan Tunku 
Canselor UM. 5 Oktober 1970, PBMUM melakukan operasi ganyang dengan mengecat merah dan hitam papan-papan tanda dan membakar surat-surat kenyataan universiti dalam Bahasa Inggeris di kampus sebagai protes tindakan universiti yang tidak menghormati pelaksanaan Bahasa Melayu sebagai bahasa kebangsaan. Ia dilakukan selepas para mahasiswa berkumpul di sudut pidato untuk mendengar ucapan berapi-api dari pimpinan PBMUM. Kejadian ini telah dipanggil Demonstrasi Papan Tanda, Peristiwa ini menyebabkan Naib Canselor ketika itu mengisytiharkan hasil mesyuarat senat yang memberitahu Bahasa Melayu merupakan Bahasa rasmi UM, pegawai yang fasih Bahasa Melayu akan didahulukan dan bahasa pengantara urusan rasmi akan dilakukan dalam Bahasa Melayu.

Politik luar negara pula mengakibatkan mahasiswa tidak berpuas hati dengan tindakan sesetengah negara yang cuba menghuru-harakan keamanan dan kesejagatan warga global. Muhammad Abu Bakar (1973) dan Ridhuan Mohamad Nor (2012) mengatakan pada tahun 1970 juga mahasiswa telah mengadakan demonstrasi menentang kerajaan British kerana menjual senjata kepada Afrika Selatan yang mengamalkan dasar aparteid telah dilaksanakan di sana. Pada 14 Jun 1971 demonstrasi oleh seramai 2000 orang mahasiswa menentang lawatan Perdana Menteri Thailand Tun Thanom Kittikachorn kerana melakukan penindasan terhadap orang Islam di Patani. Ia dimulakan dengan pidato pimpinan PMIUM dan juga Kelab Sosialis di Sudut Pidato. Ini merupakan suatu sejarah di mana ianya merupakan demonstrasi yang pertama diadakan selepas AUKU 1971 diluluskan dan telah dipimpin oleh Ismail Mina yang memegang jawatan YDP PMIUM 71/72. Ia diadakan semasa hari ketibaan perdana menteri itu bersama Menteri Luarnya, Tun Thanat Khoman. Revolusi Iran 1979 juga sangat mempengaruhi pemikiran mahasiswa. Ia turut mempengaruhi suasana kebangkitan Islam di Malaysia. Zainah Anwar (1990) menggambarkan mereka berasakan sudah tiba masanya Malaysia juga mengikut jejak langkah Iran yang mengangkat idea 'wilayah al-Faqih' dan 'kepimpinan ulama'.

\section{Akta Universiti dan Kolej Universiti}

Pada dekad ini, AUKU baru diperkenalkan oleh kerajaan pada 1971 disebabkan penyertaan mahasiswa semasa Pilihanraya Umum 1969. Walaubagaimanapun, aktivisme masih memuncak dan berjalan seperti biasa tanpa rasa takut kepada kerajaan. Selepas Peristiwa Baling, Junaidi Abu Bakar (1993) mengatakan ianya dipinda semula pada 1975 supaya lebih berkesan mengawal mahasiswa dan ditambah beberapa seksyen baharu. Selepas Peristiwa Baling, kerajaan telah mengambil tindakan dengan menghancurkan Sudut Pidato dan menurunkan papan tanda senarai pimpinan pelajar lepas bagi mengurangkan pengaruh aktivis pelajar. Walau bagaimanapun aktiviti-aktiviti dakwah diberi kelonggaran dan tidak dilihat sebagai ancaman pihak pentadbiran dan kerajaan kerana dilihat satu cara mengatasi masalah komunisme, keruntuhan moral, disiplin dan dadah di kampus.

Kesimpulannya, peristiwa 13 Mei 1969 telah memberikan kesan yang besar terhadap perkembangan gerakan mahasiswa dekad 1970-an. Kejadian itu sudah semestinya mendatangkan trauma yang tragis kepada masyarakat ketika itu. Politik juga turut terkesan dengan peristiwa 1969 di mana kerajaan mula menggerak Dasar Ekonomi Baru bagi mengurangkan jurang ekonomi antara kaum. Desakan pelajar ITM diketuai Ibrahim Ali juga merupakan manifestasi menuntut keadilan sosioekonomi dalam masyarakat. Peristiwa itu membangkitkan semangat nasionalisme bersifat Islamis dalam kalangan mahasiswa. Ia didorong oleh sifat sayang kepada bangsa dalam masa yang sama kesedaran untuk mengamalkan Islam secara menyeluruh dan bukan lagi pada hanya amalan ritual semata-mata. Islam mula dipandang oleh mahasiswa yang insaf untuk menjadi sandaran perjuangan mahasiswa dan dianggap sebagai penyelesaian kepada semua masalah. Fahaman nasionalisme juga telah dinaturalisasikan dengan fahaman Islam iaitu untuk menjaga masyarakat dan mengeluarkan masyarakat daripada kepompong kemiskinan. Islam juga menjadi asas untuk menyahkan gaya hidup mahasiswa yang dinodai dengan liberalisme dan sekularisme seperti mendedahkan aurat, pergaulan bebas dan meminum arak. 
Faktor-faktor kebebasan berfikir seperti sosioekonomi, dakwah dan kebangkitan Islam, politik dan AUKU sangat signifikan dengan kegiatan gerakan mahasiswa. Ia menjadi isu-isu yang besar dalam perjuangan mereka secara tidak langsung mendorong fikiran mereka untuk mencari penyelesaian kepada masalah berlaku. Dekad 1970-an menunjukkan ada sahaja peristiwa-peristiwa yang berlaku dan melibatkan mahasiswa. Ia menunjukkan mahasiswa sangat aktif dan sensitif dengan keadaan semasa. Mereka menjadi penggerak dan watak utama dalam peristiwa-peristiwa tersebut. Mahasiswa giat mencari penyelesaian kepada masalah sekeliling mereka. Mereka memerlukan idea untuk membawa perjuangan yang lebih terarah. Oleh itu, ideologi-ideologi digunakan untuk menggambarkan sikap dan mentaliti mereka.

Kebebasan berfikir digunakan sebaiknya oleh mahasiswa sesuai dengan keupayaan berfikir mereka bagi memberi respons terhadap perkara yang berlaku. Pelbagai kegiatan dan aksi dilakukan bagi menunjukkan ekspresi mereka yang tidak dapat dihalang oleh pihak penguasa. Kajian ini juga mendapati mahasiswa melalui zaman kegemilangannya dengan penggunaan kebebasan berfikir sebaiknya oleh mahasiswa untuk memberi khidmat kepada masyarakat dan juga memenuhi keperluan mahasiswa itu sendiri.

\section{Penghargaan}

Artikel ini adalah hasil penyelidikan dari geran Cabaran Perdana DCP-2017-013/3.

\section{References}

Badlihisham Mohd Nasir. 2015. ABIM dan PAS dalam Gerakan Dakwah Islam di Malaysia. Kuala Lumpur: Dewan Bahasa dan Pustaka.

Chandra Muzaffar. 1988. Kebangkitan Semula Islam di Malaysia. Petaling Jaya: Penerbit Fajar Bakti Sdn Bhd. Charles Allers. 2017. Anwar Ibrahim: Penampilan Demokrat Muslim. Shah Alam: IDE Research Centre Sdn. Bhd.

Ibrahim Ali. 2016. Perjuangan Tanpa Noktah: Ranjau, Onak, Fitnah \& Cemburu. Kuala Lumpur: Berita Publishing Sdn Bhd.

Ibrahim Saad. 1986. Isu Pendidikan di Malaysia. Kuala Lumpur: Dewan Bahasa dan Pustaka.

Jabatan Perangkaan Malaysia. Laporan Penyiasatan Isi Rumah dan Kemudahan Asas 2014.

Jabatan Perangkaan Malaysia. 2016. Laporan Penyiasatan Perbelanjaan Isi Rumah 2016.

Jabatan Perangkaan Malaysia 2017 Laporan Penyiasatan Penggunaan dan Capaian ICT oleh Individu dan Isi Rumah, Malaysia, 2017.

Junaidi Abu Bakar. 1993. Mahasiswa, Politik dan Undang-Undang. Kuala Lumpur: Dewan Bahasa dan Pustaka.

Mazli Mamat, Abdul Razak Abdul Rahman \& Abdul Rashid Abdullah. 2015. Penglibatan Mahasiswa Melayu Universiti Awam dalam Politik di Malaysia. Malaysian Journal of Youth Studies 23-31.

Mohd Shuhaimi Al-Maniri. 1995. Di Sebalik Tabir: Politik Kampus. Bandar Baru Bangi: Pustaka Generasi Baru.

Muhammad Abu Bakar. 1973. Mahasiswa Menggugat. Kuala Lumpur: Pustaka Antara.

Muhammad Nur Anuar. 1986. Ledakan Ubudiah: Dalam Budaya Politik Pelajar. Alor Setar: Pustaka Ikhwan. Riduan Mohamad Nor. 2012. Sejarah Gerakan Mahasiswa: Dalam Cerminan Dekad. Kuala Lumpur: Jundi Resources.

Saifuddin Abdullah. 2009. Kalau Saya Mahasiswa., http:// www. Saifuddin abdullah. com.my/ ebook / kalau saya mahasiswa 2.pdf [1 December 2018].

Shamsul Amri Baharuddin. 2007. Budaya yang Tercabar. Kuala Lumpur: Dewan Bahasa dan Pustaka. 
Sidek Baba. 2009. Fikir dan Zikir. Kuala Lumpur: Dewan Bahasa dan Pustaka.

Siti Hamisah Manan. 2009. Gelombang Kebangkitan Dakwah Kampus. Kuala Lumpur: JIMedia.

Syed Muhammad Naquib Al-Attas. 2011. Islam dan Sekularisme. Trans. Bandung: Institut Pemikiran Islam dan Pembangunan Insan (PIMPIN).

Ummi Munirah Syuhada Mohamad Zan, Faridatulazna Ahmad Shahabuddin, Nur Riza Mohd. Suradi, Mansor Mohd Noor, Wan Suraya Wan Hassin \& Wan Shahzlinda Shah Wan Shahar. 2016. Tanggungjawab Politik: Kajian dalam Kalangan Pelajar IPTA. Proceeding of the 3rd International Conference on Management \& Muamalah 2016 (3rd Icomm). 31 Oktober-1 November.

Ungku A. Aziz. 1987. Jejak-Jejak Di Pantai Zaman. Kuala Lumpur: Penerbit Universiti Malaya.

Wan Mohd Nor Wan Daud. 2017. Peranan Universiti: PengIslaman Ilmu Semasa, Penafibaratan dan Penafijajahan. Kuala Lumpur: CASIS \& HAKIM.

Weiss, Meredith L. 2016. Aktivisme Mahasiswa Malaysia. Petaling Jaya: SIRD.

Zainah Anwar. 1990. Kebangkitan Islam Di Kalangan Pelajar. Petaling Jaya: IBS Buku Sdn Bhd. Zulkifli Ismail. 2014. Ancaman Bahaya Sekularisme. Sg. Udang, Melaka: Pondok Baitul Qurra' Wal Fuqaha'. 